REFLECTIONS:

NEUROLOGY AND THE

HUMANITIES

Section Editor

Michael H. Brooke, MD

\title{
Perception of Time
}

My DNA removes all doubt,

Its time for me, there's no way out.

Sequence of breath, cold slice of clock,

Blind, dispassionate wedge of time.

Yet Life plants thoughts that ply within, Coaxing us where we've never been, No distant place, but deep within, Deep queries on Time through mind. What is Time's crux? Can we define Concept, notion, idea of time? Is Time finite? Will it run out? Can Time divide to branch new route? Can Time move on to meet itself, And circle forth - to Genesis? Does Time arise from conscious mind? Does consciousness arise from Time?

\section{II}

For Time to happen, does it need Perception by a conscious me? St. Augustine conjectured Time

Does not exist outside the mind. Could Time arise from conscious thought, From molecules that bounce in skull, Produced by brain bits, nothing more, Mere fabrication of the mind? My time may halt through dreamless sleep, But Time exists without my thought, Without my brain, or conscious lot. The face of friends, the human tale, Slow change with age, without my sight, To play its role in passing plight.

III

Does Time subserve, as roll of life Exacts its toll upon our mold: Biology's pre-programmed dirge? Even Dolly bore aging joints, As youthful lamb in Scottish field. Our bodies heed cruel clicks of clock, Apoptosis does not stop; Death by design is not denied; To living things, Time's absolute, Unstoppable! Time stops Life's route; Thus, Time draws death to grimly reap Upon each mind and mortal mass;
IV

Does Time suspend when not observed,

Events, not seen, have not occurred?

Schrödinger's cat - alive, while dead;

A zero on vast plane of Time;

Unhappenings within weird world

Of spooky quantum Bohr events.

Does Time arrest at speeds of light?

Defy the rule of Newton's world,

Majestic clock of classic thought.

To travel at that unique "c,"

Stops Time, prevents long march of age,

Upon the roiling timescape stage.

For some, time halts . . the clock seems still . . . Time's relative through Einstein's will.

V

Does Humankind unfold its Time

As chronicle of struggled breath?

From genesis to genocide,

Apocalypse, catastrophe.

Realities - breath, death and strife,

Topologies - timescapes of life.

Thus Time's straight line can stretch to plane; Brief moment now - one point in Time;

A point, on plane of space-time curve,

A point, on plain of history.

The timescape of the human tale Is rife with holes, with parapets, That pit, that pock, the course of life, Hard hateful blocks, a struggled strife.

VI

On paths pursued on time-rich plains, What are the spoils of breathing Time?

Emotions are the prize from Time! Freedom of will: notion to motion; Cerebral wine: emotion from notion.

Young couple twines, ferocious love

Too deeply binds two lives to one,

As Time befriends romantic zeal.

Like Hallmark moments: treacle, schmaltz, Is joy of joyous time for real, 
Or delude to a hopeful mind?

Like tales of Life: born, suffer, die,

Is misery the Human lot,

Or fallacy from fallen thought?

\section{VII}

Will we traverse Time's loathsome plane,

To slip this earth-bound space-time plain?

To witness wars and really know,

Who "lived, felt dawn, saw sunset glow,"

Without the victor's twist of tale.

Can thought through Art control the Time?

Picasso's cubes - Guernica -

Immobile blocks: disjoint, move, scream,

Divulge horrific sweeps of time;

Enslaving Time . . . eternity.

If we can comprehend Time's id,

Its meaning, measure, and moot point,
Then we can touch our Nature's face,

To know the plan, to know the pace.

VIII

And so through thought, can we define,

Concept, notion, idea of Time?

Time is the net that webs through brain, Time forms the flow - cerebral train;

Where Art and Science paths embrace,

Entwine - two dialects of Time.

Time does permit reality;

Two billions seconds in each Life, Each second holds eternity.

What is Time? A construct of our

Brain and mind? A paradox of

Soul? A representation of

Succession through a succession

Of representations - that is Time! 


\title{
Neurology
}

\author{
Perception of Time \\ Donald F. Weaver \\ Neurology 2008;71;1836-1837 \\ DOI 10.1212/01.wnl.0000340780.22816.19
}

This information is current as of November 24, 2008

\section{Updated Information \&}

Services

Permissions \& Licensing

Reprints including high resolution figures, can be found at: http://n.neurology.org/content/71/22/1836.full

Information about reproducing this article in parts (figures,tables) or in its entirety can be found online at:

http://www.neurology.org/about/about_the_journal\#permissions

Information about ordering reprints can be found online:

http://n.neurology.org/subscribers/advertise

Neurology ${ }^{\circledR}$ is the official journal of the American Academy of Neurology. Published continuously since 1951, it is now a weekly with 48 issues per year. Copyright. All rights reserved. Print ISSN: 0028-3878. Online ISSN: 1526-632X.

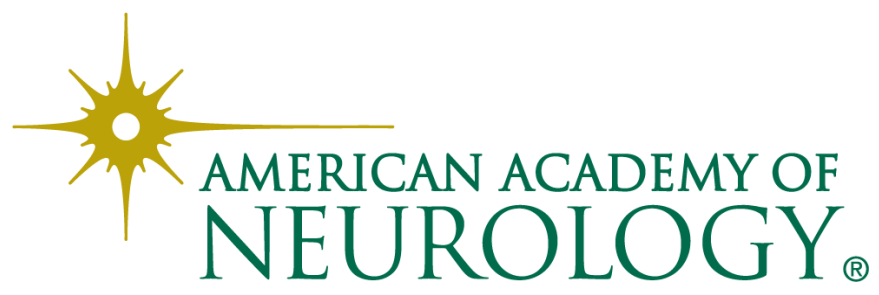

